\title{
THE PROFILE OF PORTUGUESE PEOPLE WHEN CHOOSING AN APARTMENT
}

\author{
Eulália Santos \\ Higher School of Technology and Management \\ Polytechnic Institute of Leiria \\ e-mail:eulalia.santos@ipleiria.pt \\ Fernando Tavares \\ ISCET - Higher Institute of Business and Tourism \\ e-mail: ftavares@iscet.pt
}

\begin{abstract}
It is important to study and to know the determining factors of the housing purchase business, as this is often the greatest business deal in a family's life. The purpose of this study is to identify the profile of the Portuguese regarding the determining factors when searching for apartments to acquire. The methodology used is based on a questionnaire that analyzes the determining factors in the choice of apartments to acquire and the sociodemographic profile of Portuguese people looking for an apartment. The sample consisted of 646 individuals who were looking for an apartment in different regions of Continental Portugal. The determining factors in the choice of apartments have quite adequate levels of validity and reliability, and four dimensions are obtained: negative externalities, positive externalities, a business located on the ground floor and rational interest in proximity to public services. Cluster analysis results show the formation of five clusters, classifying individuals into a generic cluster, urban business cluster, urban services cluster, urban citizens cluster and elitist cluster. This study is expected to contribute to increasing scientific knowledge on the topic and to help real estate developers better match their clients' preferences.
\end{abstract}

Key words: real estate market, housing location, real estate externalities, real estate rating, real estate risk.

JEL Classification: $R 30, R 31, R 32$.

Citation: Santos, E. \& Tavares, F. (2021). The profile of Portuguese people when choosing an apartment. Real Estate Management and Valuation, 29(2), 38-51.

DOI: https:// doi.org/10.2478/remav-2021-0012

\section{Introduction}

In the search for an apartment's location, there are variables that, due to their importance, were studied and became unavoidable over time when making this type of investment. Lepkova et al. (2017), in a study on customer satisfaction with new apartment buildings, which was carried out for Lithuania and Poland, observed that customers value the economic aspects, as well as the technical and functional characteristics of the houses. The main characteristics of technical quality that customers value are thermal insulation, sound insulation and the absence of construction defects. Although safety issues are valued, the greatest satisfaction comes from aspects related to the functional quality of the houses. Moreover, Źróbek et al. (2015) explain that the price factor remains the main determinant for buyers choosing a given residential location. This is not to say that the quality of the environment does not influence the value of the property. It is also said that the purchase of housing is the biggest investment in the lives of most families. Manzhynski et al. (2018) point out that an apartment is a good asset for meeting anyone's basic housing needs, even including the most economically disadvantaged. Calculations show that transaction costs have an important 
impact and, therefore, should be considered when purchasing a house. Źróbek et al. (2020) concluded that an important reason for purchasing a house is an improvement in the standard of living, a change in marital status and the high costs of housing rents. They observed that women, generally speaking, exhibit greater decision-making autonomy in matters of housing as compared to men. For these reasons, an impartial assessment has an important role in business transparency. Kucharska-Stasiak et al. (2018) point out that the appraiser's role is to provide unbiased assessments of value. An important phase of the assessment is the process phase. A source of bias is the customer-appraiser relationship. Knowledge of these variable leads to better decisions, because the valuation of these aspects is not trivial.

In the present study, four dimensions (factors) are presented: negative externalities, positive externalities, business located on the ground floor and the interest of proximity to public services (Tavares \& Pacheco, 2015). These dimensions (factors) result from the factorial structure obtained in the variables that evaluate the determining factors that lead a person to choose an apartment, which were presented to individuals who were looking for apartments to live in and demonstrated quite adequate levels of validity and reliability. The aim of this study is to identify the Portuguese profile regarding the determining factors in the choice of apartments.

To achieve this purpose, this article was divided into five points. In addition to this introduction, the second point presents a review of the literature, which focuses on some studies that support knowledge regarding negative and positive externalities, the types of stores and businesses that are located on the ground floor and the rational interest of proximity to public services. The third section presents the methodology used in the study. The fourth section presents the results of the study, namely exploratory and confirmatory factor analysis and cluster analysis. Finally, the conclusions are presented.

\section{Theoretical Framework}

Knowing, analyzing and valuing determining factors in choosing apartments is not an easy task. In the academic field, there are plenty of studies on the most diverse variables. The following are some of the ways for obtaining the four dimensions: negative externalities, positive externalities, business located on the ground floor of the building and the rational interest of proximity to public services.

\subsection{Negative Externalities}

Negative externalities are detrimental to the location of the apartment and naturally lead people to move away and seek residence away from it.

Negative externalities are related to the proximity to highways, to places with undesirable sights and odors, high voltage lines, landfills and crime. Areas with heavy pollution, coal-fired power plants, nuclear power plants, refineries and other activities leading to contamination that affect people's quality of life, value and property rights. Table 1 presents a summary of negative externalities and the authors who included them in their studies.

Table 1

Summary of negative externalities found in the literature

\begin{tabular}{ll}
\hline \multicolumn{1}{c}{ Negative Externality } & \multicolumn{1}{c}{ Author(s) } \\
\hline $\begin{array}{l}\text { Proximity to highways and other noises } \\
\text { Exposure to undesirable sights and odors }\end{array}$ & $\begin{array}{l}\text { Tyvimaa, Gibler and Herbert (2015); Seo, Golub and } \\
\text { Kuby (2014). }\end{array}$ \\
\hline Proximity to high voltage lines & Sims and Dent (2005); Elliott, Wadley and Han (2016). \\
\hline Landfills and delinquency & $\begin{array}{l}\text { Abidoye and Chan (2018). } \\
\text { Seo, Salon, Shilling and Kuby (2018). }\end{array}$ \\
\hline $\begin{array}{l}\text { Contaminated land, irreversible and } \\
\text { irreparable damage to nature }\end{array}$ & $\begin{array}{l}\text { Horváth and Hajnal (2014); Chen and Li (2017); Taylor, } \\
\text { Phaneuf and Liu (2016). }\end{array}$ \\
\hline $\begin{array}{l}\text { Landfill, coal-fired power plants, chemical } \\
\text { refineries, nuclear power plants, activities } \\
\text { leading to contamination }\end{array}$ & $\begin{array}{l}\text { Zhao, Xu and Liu (2018); Zhao, Simons, Li-Jun and Fen } \\
(2016) .\end{array}$ \\
\hline Landfill of debris & Seo, Salon, Shilling and Kuby (2018). \\
\hline Presence of a nearby landfill & Jauregui and Hite (2005); Chen and Li (2017). \\
\hline $\begin{array}{l}\text { Contamination affects the value and rights } \\
\text { of real estate }\end{array}$ & Simons and Saginor (2006); Chen and Li (2017). \\
\hline
\end{tabular}


Wind farms

Lang, Opaluch and Sfinarolakis (2014); Jensen, Panduro, Lundhede, Nielsen, Dalsgaard and Thorsen (2018). Hoen, Brown, Jackson, Thayer, Wiser and Cappers (2015); Dröes and Koster (2016).

Source: own study.

\subsection{Positive Externalities}

Positive externalities are amenities that people value and seek to be close to when choosing an apartment to live in. There are studies that mention the proximity to parks and green areas, the landscaping of the walks, the water views, specifically: ocean, rivers and lakes. There are also other aspects, such as the neighborhood, ecological, environmental and social benefits, which are valued by buyers. In cities, central location which values the views of the main square of the city is sought.

Table 2

Summary of positive externalities found in the literature

\begin{tabular}{|c|c|}
\hline Positive Externality & Author(s) \\
\hline Proximity to public green areas & $\begin{array}{l}\text { Czembrowski and Kronenberg (2016); Xiao, Li } \\
\text { and Webster (2016); Liebelt, Bartke and Schwarz } \\
\text { (2018); Sander and Zhao (2015). }\end{array}$ \\
\hline Proximity to the Ocean & $\begin{array}{l}\text { Gordon, Winkler, Barrett and Zumpano (2013); } \\
\text { Wyman and Worzala (2016). }\end{array}$ \\
\hline View of main square & Hananel (2017); Czinkan and Horváth (2019). \\
\hline Water view & $\begin{array}{l}\text { Bin, Gardiner, Liu and Li (2019); Jim and Chen } \\
(2009)\end{array}$ \\
\hline Landscaping of the walks & $\begin{array}{l}\text { Czembrowski and Kronenberg (2016); Metzner } \\
\text { and Kindt (2018). }\end{array}$ \\
\hline $\begin{array}{l}\text { Water view, neighborhood improvements and } \\
\text { nearby neighborhoods }\end{array}$ & $\begin{array}{l}\text { Bin, Gardiner, Liu and Li (2019); Metzner and } \\
\text { Kindt (2018). }\end{array}$ \\
\hline $\begin{array}{l}\text { Up to three garages per apartment, } \\
\text { playgrounds, swimming pool, SPA }\end{array}$ & Montero, Mínguez and Fernández-Avilés (2018). \\
\hline Ecological, environmental and social benefits & $\begin{array}{l}\text { Brastow, Waller and Wentland (2018); Mothorpe } \\
\text { and Wyman (2017). }\end{array}$ \\
\hline Proximity to rivulets and lakes & $\begin{array}{l}\text { Chen and Li (2017); Münch, Nielsen, Racz and } \\
\text { Hjalager (2016); Mothorpe and Wyman (2017). }\end{array}$ \\
\hline Neighborhood & $\begin{array}{l}\text { Arribas, García, Guijarro, Oliver and } \\
\text { Tamošiūnienė (2016); Chen and Li (2017). }\end{array}$ \\
\hline
\end{tabular}

\subsection{Proximity to business}

Source: own study.

Proximity to businesses impacts the choice and value of an apartment. When cities were first built, they had housing and work, which is the justification for shops and housing to be present in the same building in the downtown areas of cities.

Table 3

Summary of business-related externalities found in the literature

\begin{tabular}{ll}
\hline Externality related to business & Author(s) \\
\hline Units near rental areas & $\begin{array}{l}\text { Hussain, Abbas, Wei and Nurunnabi (2019); Carswell } \\
(2018) .\end{array}$ \\
\hline Proximity to clothing stores & $\begin{array}{l}\mathrm{Hu}, \mathrm{He}, \mathrm{Han}, \mathrm{Xiao}, \mathrm{Su}, \text { Weng and Cai (2019); Roth } \\
\text { and Grant (2015). }\end{array}$ \\
\hline Proximity to supermarkets & $\mathrm{Wu}$, Ye, Du and Luo (2017); Jang and Kang (2015). \\
\hline Apartments close to hair salons & Liu, Xu and Cai (2018); Cavalcanti (2016). \\
Proximity to a pharmacy and banks & $\begin{array}{l}\text { Tavares and Pacheco (2015); Cortés and Iturra (2019); } \\
\text { Renigier-Bilozor, Janowski and Walacik (2019). }\end{array}$ \\
\hline
\end{tabular}

Source: own study. 
There are businesses that people prefer to have near the residential area, such as clothing stores, a pharmacy, banks, a supermarket and a hairdresser's. These are businesses that are related to the people's everyday needs.

\subsection{Proximity to public services}

Another factor that impacts housing choice is the proximity to public services, such as schools, health services and other social and public facilities. Literature in this area also refers to the proximity to public transport, public parks, monuments and cultural facilities.

Table 4

Summary of externalities related to proximity to public services found in the literature

\begin{tabular}{ll}
\hline Proximity to public services & Author(s) \\
\hline $\begin{array}{l}\text { Proximity to schools, citizen support } \\
\text { services, public transport }\end{array}$ & $\begin{array}{l}\text { Cordera, Coppola, Dell'Olio and Ibeas (2019); } \\
\text { Finnigan and Meagher (2019); Stotz (2019). }\end{array}$ \\
\hline Proximity to public transport & Dai, Bai and Xu (2016); Li, Chen and Zhao (2019). \\
\hline Proximity to health services & $\begin{array}{l}\text { Gusmano, Rodwin and Weisz (2018); Kuehn } \\
(2019) .\end{array}$ \\
\hline $\begin{array}{l}\text { Proximity to green public spaces, good } \\
\text { parks }\end{array}$ & $\begin{array}{l}\text { Łaszkiewicz, Kronenberg and Marcinczak } \\
\text { (2018); Fernandez, Mukherjee and Scott (2018). }\end{array}$ \\
\hline Monuments and cultural facilities & $\begin{array}{l}\text { Lubberink, Post and Veuger (2018); Kim, Lee, } \\
\text { Lee and Choi (2019). }\end{array}$ \\
\hline
\end{tabular}

Source: own study.

\section{Method}

\subsection{Population and sample}

The target population of this study are individuals who were looking for an apartment in Continental Portugal. Thus, between April and September of 2019, questionnaires were distributed by numerous real estate agencies from different regions of the country, resulting in a sample of 646 individuals looking for an apartment to live in. The data collection process which was utilized consisted of applying the stratified non-probabilistic sampling method, where the questionnaire was administered nationally and intra-urbanly, taking into account the socioeconomic and demographic characteristics of the different market segments.

\subsection{Data gathering instruments}

The methodology which was used is quantitative and is based on a questionnaire survey consisting of four parts: (i) the individuals' socio-demographic profile (gender, age, marital status, household size, educational level and gross annual household income); ii) preferences, in terms of apartment typology, desired floor, number of parking spaces for cars and number of bathrooms; iii) determining factors in the choice of apartments; iv) current demand for apartments (classification and importance of the places where the search is made).

In order to analyze the determining factors in choosing apartments, 48 items were used resulting from the review of literature (Table 5). Items 37, 38, 39, 40, 41 and 42 were measured on a 5-point Likert scale (1- Very negative impact to 5- Positive impact) and assess the impact that business locations have when located on the ground floor of a building. The remaining items were evaluated on a 5-point Likert type scale of importance (1- Not important to 5 - Very important).

To classify the current demand for apartments, a 5 point Likert scale (1- Very difficult to 5- Very Easy) was used, whereas the importance of the places where the search is made (places of interest with internet, real estate, newspapers and contact with friends who know about this subject) was assessed based on a 5-point Likert-type importance scale (1- Not important to 5 - Very important) was used.

Table 5

Items that Evaluate the Determining Factors to Consider when Choosing an Apartment

\begin{tabular}{ll}
\hline It1- Proximity to schools & It25- Proximity to a landfill \\
\hline It2- Proximity to commercial areas & It26- Proximity to a high voltage line \\
\hline
\end{tabular}




\section{S sciendo}

\begin{tabular}{ll}
\hline It3- Existence of public transport & It27- Contaminated surrounding land \\
\hline It4- Proximity to health services & It28- Air pollution higher than average \\
\hline It5- Proximity to public services & It29- Proximity of solid waste burning \\
\hline It6- Proximity to recreation areas & It30- Proximity of a WWTP \\
\hline It7- Set in a quality neighborhood & It31- Sea view \\
\hline It8- Set in an area of houses for rent & It32- River view \\
\hline It9- Proximity to a reference place & It33- Park view \\
\hline It10- Proximity to work/study & It34- Mountain view \\
\hline It11- Proximity to family and friends & It35- Lagoon view \\
\hline It12- Structured area & It36- Square view \\
\hline It13- Outdoor parking & It37- Proximity to a bar/restaurant \\
\hline It14- Existence of an elevator & It38- Proximity to a pharmacy \\
\hline It15- Stairs location & It39- Proximity to a bank \\
\hline It16- Barbecue zone & It40- Proximity to a clothing store \\
\hline It17- Garbage collection & It41- Proximity to a hair salon \\
\hline It18- Doormen/concierge & It42- Proximity to a supermarket \\
\hline It19- Video intercom & It43- Room size \\
\hline It20- Material used in the roof of the building & It44- Bathroom size \\
\hline It21- Place to wash the car & It45- Living room size \\
\hline It22- Existence of outdoor green spaces & It46- Balcony size \\
\hline It23- Traffic noises & It47- Kitchen size \\
\hline It24- Proximity to a rundown park & It48- Sunroom size \\
\hline
\end{tabular}

Source: own study.

\subsection{Ethical and statistical procedures}

The participants were informed about the objectives of the study and about the confidentiality and anonymity of information provided in the questionnaire.

The IBM SPSS Statistics 25 software and the cluster analysis technique were used to define the clusters, the descriptive statistics technique was used in order to describe the sample and to characterize the profile of the individuals in the different clusters, and the statistical inference technique was used to verify the existence of significant differences in the determining factors in the choice of apartments among the clusters, and also to characterize the profile of the individuals within the clusters; lastly, it was verified in each cluster if the sociodemographic variables interfered in the determining factors in the choice of apartments. The factorial validity of the model was evaluated using exploratory and confirmatory factor analysis techniques with the help of the IBM SPSS Amos software.

\section{Empirical results}

\subsection{Sample characterization}

In order to streamline the data collection process, questionnaires were distributed by various real estate agencies in different regions of the country between April and September 2019, using the nonprobabilistic sampling method for convenience. The study sample consisted of 646 individuals looking for an apartment, aged between 19 and 68 years old, with an average of 38 years $(S D=10.90)$. Most individuals were male (54\%). Regarding marital status, $59 \%$ were married or living in a union, $32.7 \%$ were single, and $8.4 \%$ were separated/divorced/widowed. Regarding the number of household elements, the average is 3 elements per household. Regarding the level of education, $63.8 \%$ 
of the individuals have a higher education and $36.2 \%$ have elementary or secondary education. Regarding household income, $70.7 \%$ have an annual gross income of less than $30,000 €, 20.9 \%$ have an income between $30,000 €$ and $60,000 €$ and $5.6 \%$ earn more than $60,000 €$.

As for the preferences, individuals that prefer three-bedroom apartments accounted for $47.8 \%$, and, as for a two-bedroom apartment, $30.5 \%$, with the studio being the least sought after $(0.9 \%)$. Intermediate floors $(34.8 \%)$ or top floors $(31.9 \%)$ are the most sought after, with the ground floor apartments being the least sought after $(9.9 \%)$. Regarding the number of parking spaces, preferences go for 1-space $(40.6 \%)$ and 2-spaces (38.4\%). Analyzing the preferences regarding the number of bathrooms desired in an apartment, it is found that the vast majority $(63.2 \%)$ seek 2 bathrooms.

Individuals rate the current demand for apartments as difficult $(\mathrm{M}=2.46, \mathrm{SD}=1.00)$. To search for an apartment, individuals attribute greater importance to the use of the internet $(M=3.91, S D=1.00)$ or the in loco search at places of interest that have information $(M=3.80, S D=1.01)$.

\subsection{Exploratory and Confirmatory Factor Analysis}

In applying the exploratory factor analysis (EFA) to the items of Table 6, the principal components method was used, followed by a varimax rotation and the Kaiser Criterion to define the number of factors to retain. After the successive elimination of items (due to factor loadings of less than 0.50 or for being saturated in different dimensions) a 20-factor factorial solution was obtained consisting of four dimensions that together explain $67.01 \%$ of the total variance: Negative Externalities (It24, It25, It26, It27, It28, It29, It29 and It30), Positive Externalities (It31, It32, It33, It34, It35 and It36), Stores located on the ground floor of the residential building (It38, It39, It40, It41 and It42) and Rational interest in proximity to public services (It2, It3, It4 and It5).

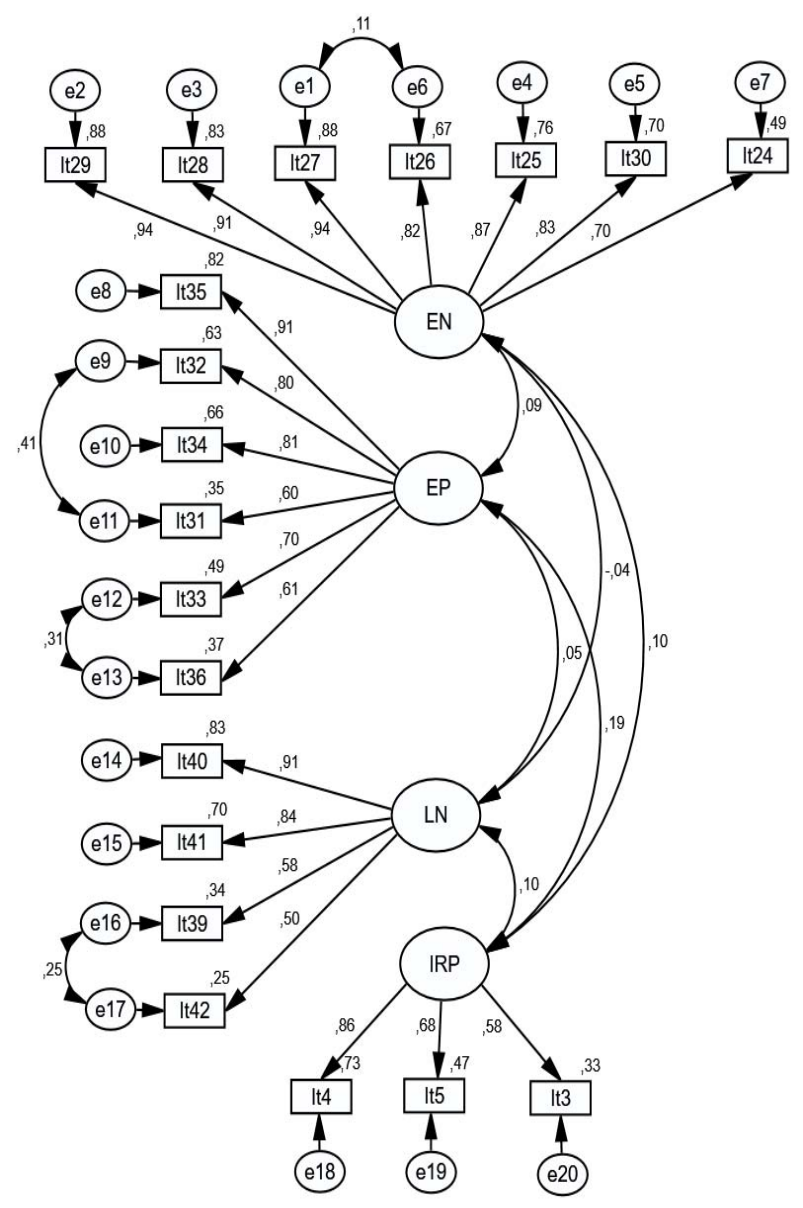

Fig. 1. Measurement Model of Determinant Factors in choosing an apartment. Source: self elaboration.

The previous structure was submitted to the application of the confirmatory factor analysis technique (maximum probability estimation method) and according to Kline (2015) and Maroco (2014), the adjustment indices showed a poor adjustment $\left(\chi^{2}=861.659, d f=203, \chi^{2} / d f=4,245, p\right.$ 
$<0.001$, GFI $=0.888$, CFI $=0.926$, RMSEA $=0.071$, PCLOSE $=0.000$, MECVI $=1.497)$. After the reformulation, the model presented in Figure 1 was obtained, consisting of four dimensions: Negative Externalities (NE), consisting of 7 items, Positive Externalities (PE), consisting of 6 items, Business located on the ground floor (BL), consisting of 4 items and Rational Interest of Proximity to Public Services (RPPS) consisting of 3 items. Items of the four dimensions have standardized the factor's mass greater than 0.5 and presented individual reliability values greater than 0.25 . The fit index of the model in Figure 1 showed good fit quality $\left(\chi^{2}=408.242, d f=160, \chi^{2} / d f=2.552, p<0.001\right.$, GFI $=0.940$, $\mathrm{CFI}=0.970, \mathrm{RMSEA}=0.049, \mathrm{PCLOSE}=0.596, \mathrm{MECVI}=0.793)$, that is, according to Kline (2015) and Maroco (2014), the Chi-Square Statistics ratio for degrees of freedom $\left(\chi^{2} / d f\right)$ below 3, GFI (Goodness of Fit Index), CFI (Comparative Fit Index) greater than 0.9, Root Mean Square Error of Approximation (RMSEA) less than or equal to 0.05, Comparative fit index (PCLOSE) greater than or equal to 0.05 and Modified expected cross-validation index (MECVI) - the smaller the better.

In Table 6, it can be observed that the dimensions of the scale of factors determining the choice of apartments are characterized by Cronbach's alpha and composite reliability (CR) values greater than 0.75 (Fornell \& Larcker, 1981; Maroco \& Garcia-Marques, 2006). The values of the AVE (Average variance extracted) in the four dimensions of the scale present values greater than 0.5 , which, according to Hair, Black, Babin and Anderson (2014), is an indicator of adequate convergent validity. Based on the AVE, MSV, and ASV parameters, it appears that, in all dimensions, the value of the AVE parameter is greater than the value of the Maximum shared variance (MSV) and Average shared variance (ASV), and the square root of the value. The stroke parameter (shown in bold in Table 6) is always superior to inter-dimension correlations (Hair et al., 2014). Thus, there is evidence of convergent and discriminant validity.

Table 6

Convergent and Discriminant Reliability and Validity

\begin{tabular}{lccccccccc}
\hline & \multicolumn{1}{c}{ CR } & & & \multicolumn{5}{c}{ Correlations } \\
\hline & $\begin{array}{l}\text { Cronbach } \\
\text { alpha }\end{array}$ & CR & AVE & MSV & ASV & NE & PE & BL & RPPS \\
\hline NE & 0.951 & 0.941 & 0.700 & 0.010 & 0.006 & $\mathbf{0 . 8 3 7}$ & & & \\
\hline PE & 0.887 & 0.879 & 0.554 & 0.035 & 0.015 & $0.086^{*}$ & $\mathbf{0 . 7 4 4}$ & & \\
\hline BL & 0.803 & 0.810 & 0.529 & 0.011 & 0.005 & -0.036 & 0.051 & $\mathbf{0 . 7 2 7}$ & \\
\hline $\begin{array}{l}\text { RPP } \\
\text { S }\end{array}$ & 0.735 & 0.754 & 0.512 & 0.035 & 0.019 & $0.100^{* * *}$ & $0.188^{* * *}$ & $0.104^{*}$ & $\mathbf{0 . 7 1 6}$ \\
\hline
\end{tabular}

" $p<0.05,{ }^{* * *} p<0.001$

Source: own study.

The representative variables of the four dimensions of the determining factors in the choice of apartments were calculated using the scores obtained in the Factor Score Weights matrix.

\subsection{Cluster Analysis}

Cluster analysis assembles subjects or variables into homogeneous groups that share one or more common characteristic (Hair et al., 2014; Maroco, 2018; Pestana \& Gageiro, 2014). In the present study, we intend to group subjects into homogeneous groups regarding the determining factors used for choosing apartments. In applying the technique, we used a hierarchical analysis through the square Euclidean distance as a measure of dissimilarity and Ward's method to group individuals with homogeneous characteristics.

According to Maroco's (2018) indications, the graphical representation of the relativized clusters distance (between 0 and 1 ) and the determination coefficient (R-squared) for solutions falling between between 2 and 8 clusters allow to conclude that the intersection between the two curves shows the existence of 5 clusters, which explain $52.36 \%$ of the total variability.

Figure 2 shows the cluster graphical representation of the mean dimensions of the determining factors in the choice of apartments. Cluster 1 is the largest with 267 (41.3\%) individuals and has higher average levels of negative externalities $(M=4.57, S D=0.48)$ and lower levels of rational interest in proximity to public services $(M=3.11, S D=0.58)$. Individuals in this cluster also consider positive 
externalities important $(M=3.72, S D=0.66)$. This cluster presents significant differences between genders in negative externalities $(t(260,799)=-2.09, p<0.05)$, positive externalities $(t(265)=2.21, p$ $<0.05)$ and rational interest in proximity to public services $(t(265)=-2.14, p<0.05)$, with women presenting higher levels of negative externalities and rational interest in proximity to public services and men presenting higher levels of positive externalities. It is noted that age is positively associated with the positive externalities $(r=0.23, p<0.001)$, the number of the members in the household is negatively associated with the positive externalities $(r=-0.13, p<0.05)$, the annual net income shows a negative relation with the rational interests of proximity to public services $(r h o=-0.16, p<0.05)$ and educational level is associated negatively with positive externalities $(r h o=-0.12, p<0.05)$ and business location on the ground floor ( $r h o=-0.14, p<0.05)$.

Cluster 2 is composed of $167(25.9 \%)$ individuals and has a higher average value in negative externalities $(M=4.43, S D=0.56)$ along with a lower average value in positive externalities $(M=2.08$, $S D=0.48$ ). This cluster presents significant differences between genders in positive externalities $(t(165)=2.52, p<0.05)$, with men presenting higher levels. It is also found that the number of members in the household $(r=-0.23, p<0.01)$ and annual gross income $(r h o=-0.22, p<0.01)$ are negatively related to the rational interest of proximity to public services, and the educational level is positively associated with positive $(r h o=0.18, p<0.05)$ and negative $(r h o=0.20, p<0.05)$ externalities.

Cluster 3 is composed of $115(17.8 \%)$ individuals and has the highest average value in negative externalities $(M=4.54, S D=0.46)$ and lowest average value in ground floor business location $(M=1.67, S D=0.46)$. In this cluster, age $(r=0.26, p<0.01)$, annual net income ( $r$ ro $=0.33, p<0.001)$ and educational level ( $r h o=0.25, p<0.01)$ are positively related to negative externalities. Cluster 4 is the least numerous, with only $32(5 \%)$ individuals and has the lowest levels of importance, being the highest average level obtained in positive externalities $(M=2.85, S D=0.87)$ and the lowest in negative externalities $(M=2.01, S D=0.73)$. In this cluster it can be inferred that the higher annual net income is associated with higher levels of rational interest in proximity to public services ( $r h o=0.36, p<0.05$ ).

Cluster 5 is composed of $65(10.1 \%)$ individuals and is characterized by having high average levels in negative $(M=4.63, S D=0.36)$ and positive $(M=4.15, S D=0.48)$ externalities, and low levels in business location on the ground floor $(M=1.67, S D=0.46)$. In this cluster, it can be inferred that higher educational level is associated with higher levels of rational interest in proximity to public services $(r h o=0.25, p<0.05)$.

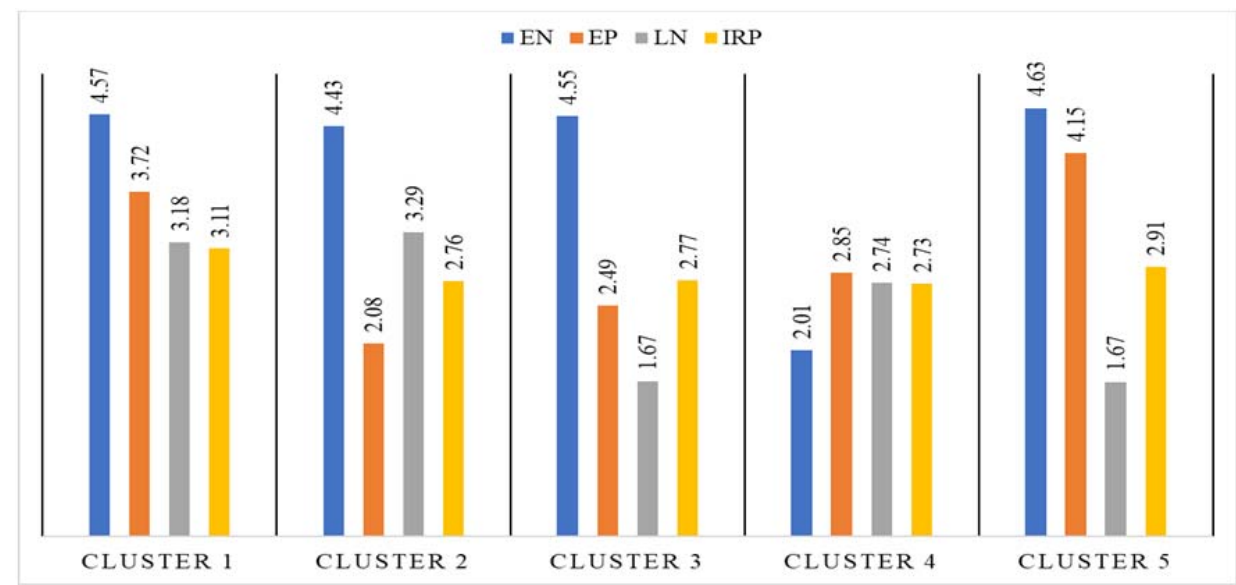

Fig. 2. The Average values of the Dimensions in Determinant Factors in Choosing Apartments per Cluster. Source: own study.

Table 7 shows the characterization of the clusters from the average of the items that analyze the determining factors when choosing an apartment. Since one of the assumptions for the application of ANOVA is not verified (Levene's test indicates that the homogeneity of variance hypothesis is not rejected) the alternative resorted to the use of Welch's test and thus concluded that there are statistically significant $(p<0.001)$ differences in the means of the various dimensions and also in the average values of the different items that evaluate the determining factors in the choice of apartments among the 5 clusters.

To find out in which clusters the significant differences are verified, the Games-Howell multiple comparison test was applied. In terms of negative externalities, cluster 4 differs significantly from the 
others $(p<0.001)$. Regarding positive externalities, clusters 3 and 4 have identical averages and all others have statistically significant differences between them $(p<0.001)$. As for the business located on the ground floor, clusters 1 and 2 as well as 3 and 5 have identical averages, and all others have statistically significant differences between them $(p<0.05)$. Finally, regarding the rational interest of proximity to public services, only statistically significant differences are observed between clusters 1 and 2 and clusters 1 and $3(p<0.001)$. Thus, the presented results allow us to infer that individuals show different interests when choosing an apartment, both in terms of the dimensions and items of the determinant factors scale, because the behaviors in the items are reflected in the dimensions.

Table 7

Characterization of Clusters through Determinant Factors when choosing an apartment

\begin{tabular}{lcccccc}
\hline & \multicolumn{5}{c}{ Mean Clusters } & Welch \\
\cline { 2 - 6 } & 1 & 2 & 3 & 4 & 5 & Test -F \\
\hline Negative Externalities & $\mathbf{4 . 5 7}$ & $\mathbf{4 . 4 3}$ & $\mathbf{4 . 5 4}$ & $\mathbf{2 . 0 1}$ & $\mathbf{4 . 6 3}$ & $\mathbf{9 6 . 6 2 ^ { * * * }}$ \\
\hline It27- Contaminated surrounding land & 4.72 & 4.57 & 4.70 & 1.91 & 4.74 & $90.83^{* * *}$ \\
\hline It29- Proximity of solid waste burning & 4.71 & 4.59 & 4.74 & 2.06 & 4.86 & $75.98^{* * *}$ \\
\hline It28- Higher than average air pollution & 4.68 & 4.51 & 4.66 & 2.03 & 4.80 & $82.67^{* * *}$ \\
\hline It25- Proximity to a landfill & 4.67 & 4.55 & 4.60 & 2.16 & 4.58 & $46.04^{* * *}$ \\
\hline It30- Proximity to a WWTP & 4.61 & 4.53 & 4.50 & 2.13 & 4.62 & $73.63^{* * *}$ \\
\hline It26- Proximity to a high voltage line & 4.50 & 4.37 & 4.51 & 1.97 & 4.58 & $65.98^{* * *}$ \\
\hline It24- Proximity to a degraded park & 4.42 & 4.26 & 4.41 & 2.56 & 4.49 & $17.39^{* * *}$ \\
\hline Positive Externalities & 3.72 & $\mathbf{2 . 0 8}$ & $\mathbf{2 . 4 9}$ & $\mathbf{2 . 8 4}$ & $\mathbf{4 . 1 5}$ & $\mathbf{3 4 0 . 4 2 ^ { * * * }}$ \\
\hline It35- Lagoon view & 3.61 & 1.81 & 2.17 & 2.69 & 4.20 & $316.84^{* * *}$ \\
\hline It32- River view & 3.67 & 2.05 & 2.62 & 2.97 & 4.25 & $138.32^{* * *}$ \\
\hline It34- Mountain view & 3.78 & 2.05 & 2.53 & 2.81 & 4.08 & $139.89^{* * *}$ \\
\hline It33- Park view & 3.81 & 2.42 & 2.84 & 2.97 & 4.00 & $66.29^{* * * *}$ \\
\hline It31- Sea view & 3.84 & 2.61 & 3.17 & 3.34 & 4.34 & $45.77^{* * *}$ \\
\hline It36- Square view & 3.36 & 2.19 & 2.45 & 2.72 & 3.20 & $42.89^{* * *}$ \\
\hline Business location on the ground floor & $\mathbf{3 . 1 8}$ & $\mathbf{3 . 2 9}$ & $\mathbf{1 . 6 7}$ & $\mathbf{2 . 7 4}$ & $\mathbf{1 . 6 7}$ & $\mathbf{3 3 4 . 6 6 ^ { * * * }}$ \\
\hline It40- Proximity to a clothing store & 3.37 & 3.52 & 1.69 & 2.94 & 1.63 & $305.31^{* * *}$ \\
\hline It41- Proximity to a hair salon & 3.34 & 3.50 & 1.73 & 2.69 & 1.68 & $183.38^{* * *}$ \\
\hline It39- Proximity to a bank & 3.70 & 3.66 & 2.45 & 3.41 & 2.68 & $35.51^{* * *}$ \\
\hline It42- Proximity to a supermarket & 3.64 & 3.68 & 2.35 & 3.38 & 2.66 & $26.28^{* * *}$ \\
\hline Rational interest of proximity to public services & $\mathbf{3 . 1 1}$ & $\mathbf{2 . 7 6}$ & $\mathbf{2 . 7 7}$ & $\mathbf{2 . 7 3}$ & $\mathbf{2 . 9 1}$ & $\mathbf{1 1 . 5 3 ^ { * * * }}$ \\
\hline It4- Proximity to health services & 4.07 & 3.69 & 3.70 & 3.63 & 3.83 & $6.08^{* * *}$ \\
\hline It5- Proximity to public services & 3.48 & 2.99 & 3.09 & 3.16 & 3.23 & $6.62^{* * *}$ \\
\hline It3- Existence of public transport & 3.97 & 3.47 & 3.48 & 3.50 & 3.65 & $6.70^{* * * *}$ \\
\hline
\end{tabular}

${ }^{* * *} p<0.001$

Source: own study.

Table 8 presents the results of the Welch test to compare the average levels of importance given to the different search locations among the 5 clusters. The use of this test as an alternative to ANOVA is justified due to the non-verification of variance homogeneity (Levene's test). The results in Table 8 show that there are significant differences between clusters in the internet search $(p<0.01)$, real estate search $(p<0.05)$, search contacting knowledgeable friends $(p<0.01)$ and newspaper search $(p<0.05)$. Using Games-Howell's multiple comparison test, only statistically significant differences were found in the internet search between clusters 1 and $4(p<0.05)$ and between clusters 4 and $5(p<0.05)$.

It is also observed that individuals from clusters 1, 3 and 5 attach high importance to searching on the internet and in places of interest with personal contacts. Cluster 2 individuals attach high importance to searching on the internet and through a real estate agent, whereas cluster 4 individuals 
attribute roughly the same importance to searching on the internet, places of interest, real estate agencies and with the help of knowledgeable friends.

Table 8

Importance of the search sites for clusters nowadays

\begin{tabular}{|c|c|c|c|c|c|c|}
\hline & \multicolumn{5}{|c|}{ Mean Clusters } & \multirow{2}{*}{$\begin{array}{l}\text { Welch } \\
\text { test - F }\end{array}$} \\
\hline & 1 & 2 & 3 & 4 & 5 & \\
\hline Search in places of interest with contact & 3.84 & 3.74 & 3.85 & 3.34 & 3.92 & 2.36 \\
\hline Search on the internet & 4.03 & 3.83 & 3.84 & 3.41 & 4.09 & $3.54^{* *}$ \\
\hline Search in real estate agencies & 3.74 & 3.80 & 3.67 & 3.03 & 3.64 & $3.31^{*}$ \\
\hline $\begin{array}{l}\text { Search with the help of knowledgeable } \\
\text { friends }\end{array}$ & 3.74 & 3.60 & 3.39 & 3.22 & 3.40 & $3.76^{* *}$ \\
\hline Search in newspaper & 2.84 & 2.60 & 2.51 & 2.88 & 2.49 & $2.49^{*}$ \\
\hline
\end{tabular}

${ }^{* * * *} p<0.001,{ }^{* *} p<0.01$ e ${ }^{*} p<0.05$

Source: own study.

Considering all the elements under analysis, Cluster 1 is referred to as a "generic cluster". This cluster represents almost half of respondent's preferences, which means that it represents the majority of individuals seeking an apartment for housing needs. Cluster 2 will be referred to as the "Urban Business Cluster". This cluster differs from the others by valuing proximity to businesses. It seeks to distance itself from negative externalities, but is ready to trade positive externalities for living close to work. Cluster 3 is called the "Urban Services Cluster". This cluster of individuals aims to move away from negative externalities and commercial areas, but to be close to public services, transport and health services.

Cluster 4 will be referred as the "Urban Citizens Cluster". This cluster of individuals' values is close to public services and businesses with positive externalities, but not concerned with negative externalities. Finally, Cluster 5 will be referred as the "elitist cluster". Individuals have the biggest concerns (remoteness, disgust) toward negative externalities, value positive externalities (are drawn to them) and seek proximity to public services.

\section{Discussion and conclusions}

The instrument used was adequate for evaluating the determining factors in the choice of apartments in the Continental Portugal, presenting a four-dimensional structure with adequate validity and reliability levels. The first dimension was called Negative Externalities (contaminated land, solid waste burning, air pollution, landfills, proximity to WWTP, high voltage lines and degraded parks) due to participant's concern about keeping them away of their future residence. The second dimension was called Positive Externalities (sea, river, lagoon, mountain, park and square views) by the participant's desire to keep them close to their future apartment. The third dimension has been referred to as Businesses Located on the Ground Floor (proximity to clothing stores, hairdressers, banks and supermarkets) because of the concern for positive or negative aspects regarding the type of businesses that are located on the ground floor of a building. The fourth and final dimension was called Rational Interest of Proximity to Public Services (proximity to health services, public services and existence of public transport) due to the buyers' concerns regarding the proximity to certain places of interest. These results follow the results of the exploratory study of Tavares and Pacheco (2015).

According to the literature and after applying the multivariate cluster analysis technique, it the existence of 5 clusters of individuals regarding the determining factors in the choice of apartments: Generic cluster; Urban business cluster; Urban services cluster; Urban citizens cluster; Elitist cluster. Common to all of them is the revulsion caused by negative externalities. Positive externalities are valued and substantially shaped by the elitist cluster. Individuals from the 5 defined clusters showed different interests regarding the different dimensions of the determining factors in the choice of apartments. This study is innovative regarding this conclusion, because it is not known to the present date which focuses on this aspect a study for Portugal.

It is expected that this study will help academics, researchers and professionals to better understand the determining factors in the choice of apartments in Continental Portugal. The results 


\section{$\$$ sciendo}

obtained and the differentiation of the 5 groups deserve greater attention from property developers who seek to meet customers' preferences in order to provide them with a more personalized service according to the group to which this customer belongs.

Keeping in mind the characteristics of individuals who are looking for housing, on the supply side there must be professionals capable of understanding in which cluster the customers are, so that their guidance is easier, therefore streamlining and optimizing the sale process.

In the future, we intend to study the plausibility of the measurement model in a study adjusted to groups such as men and women, different age groups, different income levels and different levels of education. It will also be interesting, regarding future investigation, to study if the evaluation models present all available information, or if they suffer impacts of hidden information, as studied by Kazak et al. (2019). Still another aspect to develop is to study whether social housing, increased by public entities, corresponds to the expectations of the clusters to which it is directed, or if it moves away from good locations to places of cheap land.

\section{References}

Abidoye, R. B., \& Chan, A. P. (2018). Hedonic Valuation of Real Estate Properties in Nigeria. Journal of African Real Estate Research, 3(1), 122-140. https://doi.org/10.15641/jarer.v1i1.452

Abidoye, R. B., \& Chan, A. P. C. (2018). Hedonic Valuation of Real Estate Properties in Nigeria: Hedonic Valuation of Properties in Nigeria. Journal of African Real Estate Research, 3(1), 122-140. https://doi.org/10.15641/jarer.v1i1.452

Arribas, I., García, F., Guijarro, F., Oliver, J., \& Tamošiūnienè, R. (2016). Mass appraisal of residential real estate using multilevel modelling. International Journal of Strategic Property Management, 20(1), 77-87. https://doi.org/10.3846/1648715X.2015.1134702

Bin, J., Gardiner, B., Liu, Z., \& Li, E. (2019). Attention-based multi-modal fusion for improved real estate appraisal: A case study in Los Angeles. Multimedia Tools and Applications, 78(22), 3116331184. https://doi.org/10.1007/s11042-019-07895-5

Brastow, R. T., Waller, B. D., \& Wentland, S. A. (2018). Temporally Dynamic Externalities and Real Estate Liquidity. Journal of Real Estate Research, 40(2), 199-240. https://doi.org/10.1080/10835547.2018.12091498

Carswell, A. T. (2018). Living where you work: Determining the value-added nature of the on-site residential property manager. Facilities, 36(5/6), 258-271. https://doi.org/10.1108/F-12-2016-0106

Cavalcanti, A. R. C. (2016). How Does Work Shape Informal Cities? The Critical Design of Cities and Housing in Brazilian Slums. The Plant Journal, 1(2), 319-333.

Chen, W. Y., \& Li, X. (2017). Cumulative impacts of polluted urban streams on property values: A 3-D spatial hedonic model at the micro-neighborhood level. Landscape and Urban Planning, 162, 1-12. https://doi.org/10.1016/i.landurbplan.2017.01.012

Cordera, R., Coppola, P., dell'Olio, L., \& Ibeas, Á. (2019). The impact of accessibility by public transport on real estate values: A comparison between the cities of Rome and Santander. Transportation Research Part A, Policy and Practice, 125, 308-319. https://doi.org/10.1016/j.tra.2018.07.015

Cortés, Y., \& Iturra, V. (2019). Market versus public provision of local goods: An analysis of amenity capitalization within the Metropolitan Region of Santiago de Chile. Cities (London, England), 89, 92104. https://doi.org/10.1016/i.cities.2019.01.015

Czembrowski, P., \& Kronenberg, J. (2016). Hedonic pricing and different urban green space types and sizes: Insights into the discussion on valuing ecosystem services. Landscape and Urban Planning, 146, 11-19. https:// doi.org/10.1016/j.landurbplan.2015.10.005

Czinkan, N., \& Horváth, Á. (2019). Determinants of housing prices from an urban economic point of view: Evidence from Hungary. Journal of European Real Estate Research, 12(1), 2-31. https://doi.org/10.1108/JERER-10-2017-0041

Dai, X., Bai, X., \& Xu, M. (2016). The influence of Beijing rail transfer stations on surrounding housing prices. Habitat International, 55, 79-88. https:// doi.org/10.1016/j.habitatint.2016.02.008

Dröes, M. I., \& Koster, H. R. (2016). Renewable energy and negative externalities: The effect of wind turbines on house prices. Journal of Urban Economics, 96, 121-141. https://doi.org/10.1016/j.jue.2016.09.001 
Elliott, P., Wadley, D., \& Han, J. H. (2016). Determinants of homeowners' attitudes to the installation of high-voltage overhead transmission lines. Journal of Environmental Planning and Management, 59(4), 666-686. https:/ / doi.org/10.1080/09640568.2015.1035776

Fernandez, L., Mukherjee, M., \& Scott, T. (2018). The effect of conservation policy and varied open space on residential property values: A dynamic hedonic analysis. Land Use Policy, 73, 480-487. https://doi.org/10.1016/j.landusepol.2017.12.058

Finnigan, R., \& Meagher, K. D. (2019). Past Due: Combinations of Utility and Housing Hardship in the United States. Sociological Perspectives, 62(1), 96-119. https://doi.org/10.1177/0731121418782927

Fornell, C., \& Larcker, D. F. (1981). Evaluating structural equation models with unobservable variables and measurement error. JMR, Journal of Marketing Research, 18, 39-50. https://doi.org/10.1177/002224378101800104

Gordon, B., Winkler, D., Barrett, D., \& Zumpano, L. (2013). The effect of elevation and corner location on oceanfront condominium value. Journal of Real Estate Research, 35(3), 345-364. https://doi.org/10.1080/10835547.2013.12091370

Gusmano, M. K., Rodwin, V. G., \& Weisz, D. (2018). Medicare beneficiaries living in housing with supportive services experienced lower hospital use than others. Health Affairs (Project Hope), 37(10), 1562-1569. https://doi.org/10.1377/hlthaff.2018.0070 PMID:30273020

Hair, J. F., Black, W. C., Babin, B. J., \& Anderson, R. E. (2014). Multivariate Data Analysis (7th ed.). Pearson.

Hananel, R. (2017). From central to marginal: The trajectory of Israel's public-housing policy. Urban Studies (Edinburgh, Scotland), 54(11), 2432-2447. https://doi.org/10.1177/0042098016649323

Hoen, B., Brown, J. P., Jackson, T., Thayer, M. A., Wiser, R., \& Cappers, P. (2015). Spatial hedonic analysis of the effects of US wind energy facilities on surrounding property values. The Journal of Real Estate Finance and Economics, 51(1), 22-51. https://doi.org/10.1007/s11146-014-9477-9

Horváth, K., \& Hajnal, I. (2014). Value impairment of contaminated real estate. Periodica Polytechnica Social and Management Sciences, 22(2), 141-148. https://doi.org/10.3311/PPso.7389

Hu, L., He, S., Han, Z., Xiao, H., Su, S., Weng, M., \& Cai, Z. (2019). Monitoring housing rental prices based on social media: An integrated approach of machine-learning algorithms and hedonic modeling to inform equitable housing policies. Land Use Policy, 82, 657-673. https://doi.org/10.1016/j.landusepol.2018.12.030

Hussain, T., Abbas, J., Wei, Z., \& Nurunnabi, M. (2019). The Effect of Sustainable Urban Planning and Slum Disamenity on The Value of Neighboring Residential Property: Application of The Hedonic Pricing Model in Rent Price Appraisal. Sustainability (Basel), 11(4), 1144. https://doi.org/10.3390/su11041144

Jang, M., \& Kang, C. D. (2015). Retail accessibility and proximity effects on housing prices in Seoul, Korea: A retail type and housing submarket approach. Habitat International, 49, 516-528. https:// doi.org/10.1016/j.habitatint.2015.07.004

Jauregui, A., \& Hite, D. (2005). Don't Ask, Don't Tell: The impact of real estate agents on house prices near environmental disamenities. Selected Paper, American Social Sciences Association Annual Meeting, AREUEA Session, Philadelphia, PA.

Jensen, C. U., Panduro, T. E., Lundhede, T. H., Nielsen, A. S. E., Dalsgaard, M., \& Thorsen, B. J. (2018). The impact of on-shore and off-shore wind turbine farms on property prices. Energy Policy, 116, 5059. https://doi.org/10.1016/j.enpol.2018.01.046

Jim, C. Y., \& Chen, W. Y. (2009). Value of scenic views: Hedonic assessment of private housing in Hong Kong. Landscape and Urban Planning, 91(4), 226-234. https://doi.org/10.1016/j.landurbplan.2009.01.009

Kazak, J. K., Simeunović, N., \& Hendricks, A. (2019). Hidden Public Value Identification of Real Estate Management Decisions. Real Estate Management and Valuation, 27(4), 96-104. https://doi.org/10.2478/remav-2019-0039

Kim, H. S., Lee, G. E., Lee, J. S., \& Choi, Y. (2019). Understanding the local impact of urban park plans and park typology on housing price: A case study of the Busan metropolitan region, Korea. Landscape and Urban Planning, 184, 1-11. https:// doi.org/10.1016/j.landurbplan.2018.12.007

Kline, R. B. (2015). Principles and Practice of Structural Equation Modeling (4th ed.). Guilford Press. 
Kucharska-Stasiak, E., Źróbek, S., \& Cellmer, R. (2018). Forms and Effectiveness of the Client's Influence on the Market Value of Property-Case Study. Real Estate Management and Valuation, 26(3), 82-92. https://doi.org/10.2478/remav-2018-0027

Kuehn, B. M. (2019). Hospitals Turn to Housing to Help Homeless Patients. Journal of the American Medical Association, 321(9), 822-824. https://doi.org/10.1001/jama.2018.21476 PMID:30758505

Lang, C., Opaluch, J. J., \& Sfinarolakis, G. (2014). The windy city: Property value impacts of wind turbines in an urban setting. Energy Economics, 44, 413-421. https://doi.org/10.1016/j.eneco.2014.05.010

Łaszkiewicz, E., Kronenberg, J., \& Marcińczak, S. (2018). Attached to or bound to a place? The impact of green space availability on residential duration: The environmental justice perspective. Ecosystem Services, 30, 309-317. https://doi.org/10.1016/j.ecoser.2017.10.002

Lepkova, N., Vilutienè, T., Bełej, M., Putek-Szeląg, E., \& Źróbek, S. (2017). Comparative Analysis of Newly-Built Housing Quality in Poland and Lithuania. Real Estate Management and Valuation, 25(4), 85-98. https://doi.org/10.1515/remav-2017-0032

Li, S., Chen, L., \& Zhao, P. (2019). The impact of metro services on housing prices: A case study from Beijing. Transportation, 46(4), 1291-1317. https://doi.org/10.1007/s11116-017-9834-7

Liebelt, V., Bartke, S., \& Schwarz, N. (2018). Hedonic pricing analysis of the influence of urban green spaces onto residential prices: The case of Leipzig, Germany. European Planning Studies, 26(1), 133157. https:// doi.org/10.1080/09654313.2017.1376314

Liu, N., Xu, L., \& Cai, Y. (2018). Methyl siloxanes in barbershops and residence indoor dust and the implication for human exposures. The Science of the Total Environment, 618, 1324-1330. https://doi.org/10.1016/j.scitotenv.2017.09.250 PMID:29042087

Lubberink, A. S., Van der Post, W., \& Veuger, J. (2018). Valuation of real estate market values as an indicator. Real Estate Finance, 34(4), 159-168.

Manzhynski, S., Źróbek, S., Batura, O., \& Zysk, E. (2018). Why the market value of residential premises and the costs of its purchase differ: The examples of Belarus and Poland. Land Use Policy, 71, 530-539. https://doi.org/10.1016/j.landusepol.2017.11.012

Maroco, J. (2014). Análise de equações estruturais: Fundamentos teóricos, Software and Aplicações (2nd ed.). ReportNumber.

Maroco, J. (2018). Análise Estatística com o SPSS Statistics 25 (7th ed.). ReportNumber.

Maroco, J., \& Garcia-Marques, T. (2006). Qual a fiabilidade do alfa de Cronbach? Questões antigas e soluções modernas? Laboratório de Psicologia, 4(1), 65-90.

Metzner, S., \& Kindt, A. (2018). Determination of the parameters of automated valuation models for the hedonic property valuation of residential properties: A literature-based approach. International Journal of Housing Markets and Analysis, 11(1), 73-100. https://doi.org/10.1108/IJHMA-02-2017$\underline{0018}$

Montero, J. M., Mínguez, R., \& Fernández-Avilés, G. (2018). Housing price prediction: Parametric versus semi-parametric spatial hedonic models. Journal of Geographical Systems, 20(1), 27-55. https://doi.org/10.1007/s10109-017-0257-y

Mothorpe, C., \& Wyman, D. (2017). Appraisal of Residential Water View Properties. The Appraisal Journal, 85(2), 130-141.

Münch, A., Nielsen, S. P. P., Racz, V. J., \& Hjalager, A. M. (2016). Towards multifunctionality of rural natural environments? - An economic valuation of the extended buffer zones along Danish rivers, streams and lakes. Land Use Policy, 50, 1-16. https:// doi.org/10.1016/j.landusepol.2015.08.024

Pestana, M. H., \& Gageiro, J. N. (2014). Análise de dados em Ciências Sociais - A complementaridade do SPSS (6th ed.). Sílabo.

Renigier-Bilozor, M., Janowski, A., \& Walacik, M. (2019). Geoscience Methods in Real Estate Market Analyses Subjectivity Decrease. Geosciences, 9(3), 130. https:// doi.org/10.3390/geosciences 9030130

Roth, N., \& Grant, J. (2015). The story of a commercial street: Growth, decline, and gentrification on Gottingen Street, Halifax. Urban History Review. Revue d'Histoire Urbaine, 43(2), 38-53. https://doi.org/10.7202/1031289ar

Sander, H. A., \& Zhao, C. (2015). Urban green and blue: Who values what and where? Land Use Policy, 42, 194-209. https://doi.org/10.1016/j.landusepol.2014.07.021

Seo, K., Golub, A., \& Kuby, M. (2014). Combined impacts of highways and light rail transit on residential property values: A spatial hedonic price model for Phoenix, Arizona. Journal of Transport Geography, 41, 53-62. https://doi.org/10.1016/j.jtrangeo.2014.08.003 
Seo, K., Salon, D., Shilling, F., \& Kuby, M. (2018). Pavement Condition and Residential Property Values: A Spatial Hedonic Price Model for Solano County, California. Public Works Management $\mathcal{E}$ Policy, 23(3), 243-261. https://doi.org/10.1177/1087724X18757535

Simons, R. A., \& Saginor, J. D. (2006). A Meta-analysis of the effect of environmental contamination and positive amenities on residential real estate values. Journal of Real Estate Research, 28(1), 71-104. https://doi.org/10.1080/10835547.2006.12091168

Sims, S., \& Dent, P. (2005). High-voltage overhead power lines and property values: A residential study in the UK. Urban Studies (Edinburgh, Scotland), 42(4), 665-694. https:// doi.org/10.1080/00420980500060541

Stotz, O. (2019). The perception of homeownership utility: Short-term and long-term effects. Journal of Housing Economics, 44, 99-111. https://doi.org/10.1016/j.jhe.2018.11.003

Tavares, F. O., \& Pacheco, L. (2015). Factores determinantes na escolha de apartamentos: Estudo empírico em Portugal. International Journal of Marketing. Communication and New Media, 4(3), 5-26.

Taylor, L. O., Phaneuf, D. J. and Liu, X. (2016). Disentangling property value impacts of environmental contamination from locally undesirable land uses: Implications for measuring post-cleanup stigma. Journal of Urban Economics, 93, 85-98. https://doi.org/10.1016/j.jue.2016.03.004

Tyvimaa, T., Gibler, K. M., \& Zahirovic-Herbert, V. (2015). The effect of ground leases on house prices in Helsinki. Journal of Housing and the Built Environment, 30(3), 451-470. https://doi.org/10.1007/s10901-014-9424-3

Wu, C., Ye, X., Du, Q., \& Luo, P. (2017). Spatial effects of accessibility to parks on housing prices in Shenzhen, China. Habitat International, 63, 45-54. https://doi.org/10.1016/j.habitatint.2017.03.010

Wyman, D., \& Worzala, E. (2016). Dockin'USA - A Spatial Hedonic Valuation of Waterfront Property. Journal of Housing Research, 25(1), 65-80. https:// doi.org/10.1080/10835547.2016.12092113

Xiao, Y., Li, Z., \& Webster, C. (2016). Estimating the mediating effect of privately-supplied green space on the relationship between urban public green space and property value: Evidence from Shanghai, China. Land Use Policy, 54(54), 439-447. https://doi.org/10.1016/j.landusepol.2016.03.001

Zhao, Q., Simons, R. A., Li-jun, F., \& Fen, Z. (2016). The effect of the Nengda incineration plant on residential property values in Hangzhou, China. Journal of Real Estate Literature, 24(1), 85-102. https://doi.org/10.1080/10835547.2016.12090425

Zhao, Q., Xu, Q., \& Liu, M. (2018). Case Study: Brownfield Externalities' Valuation in Wuhan, China. Journal of Sustainable Real Estate, 10(1), 59-80. https://doi.org/10.1080/10835547.2018.12091912

Źróbek, S., Trojanek, M., Źróbek-Sokolnik, A., \& Trojanek, R. (2015). The influence of environmental factors on property buyers' choice of residential location in Poland. Journal of International Students, 7(3), 163-173. https://doi.org/10.14254/2071-8330.2015/8-3/13

Źróbek, S., Zysk, E., Bełej, M., \& Lepkova, N. (2020). Do Women Affect the Final Decision on the Housing Market? A Case Study. Sustainability, 12(11), 4652.4652 ; https://doi.org/10.3390/su12114652 